\title{
Meningkatkan Kemampuan Menulis dan Self-Efficacy Mahasiswa Pada Mata Kuliah Intermediate Writing Dengan Metode Self-Assessment
}

\author{
${ }^{1}$ Annisah, ${ }^{2}$ Samsudin, ${ }^{3}$ Waliyudin \\ ${ }^{123}$ STKIP Taman Siswa Bima \\ Email: annisahnukman@gmai.co, samsudinspdmor@gmail.com, waliyudinkhalik@gmail.com
}

\begin{abstract}
Abstrak (Indonesia)
Penelitian ini bertujuan untuk meningkatkan kemampuan menulis dan self-afficacy mahasiswa dengan menggunakan metode penilaian self-assessment. Penelitian ini akan diterapkan pada mata kuliah Intermediate Writing. Metode yang digunakan adalah pre-eksperimen dengan desain one pretest dan posttest. Sampel yang digunakan pada penelitian ini adalah mahasiswa semester II Program Studi pendidikan Bahasa Inggris STKIP Taman Siswa Bima yang berjumlah satu kelas. Tahap penelitian dilakukan dalam 3 tahap yang mencakup; Tahap I: melakukan observasi dan wawancara, penyusunan instrument, penyusunan materi ajar, validasi instrument, uji coba instrument, menganalisis hasil uji coba instrument untuk mengetahui validitas dan reliabilitasnya. Tahap II: melakukan pretest, treatment, observasi, dan posttest. Tahap III: mengolah data hasil pretest, posttest, dan instrument lainnya, membandingkan hasil sebelum dan sesudah pemberian treatment, memberikan saran dan kesimpulan. Hasil yang diperoleh pada penelitian adalah terjadi peningkatan kemampuan menulis dan self-efficacy mahasiswa pada mata kuliah Intermediate Writing. hasil pre-test menunjukkan nilai minimum yang diperoleh mahasiswa adalah 43 dan nilai maksimum adalah 65, sedangkan pada post test terjadi peningkatan yang cukup baik yaitu nilai minimum yang diperoleh mahasiswa adalah 75 dan nilai maksimum adalah 90 .
\end{abstract}

Kata Kunci: kemampuan menulis, self-efficacy, Intermediate Writing, self-assessment.

\section{PENDAHULUAN}

Writing merupakan salah satu mata kuliah skill yang wajib dikuasai oleh mahasiswa pada Program Studi Pendidikan Bahasa Inggris STKIP Taman Siswa Bima. Mata kuliah ini terdiri atas tiga jenjang yang dibagi dalam tiga semester yaitu; mata kuliah Basic writing, Intermediate Writing, dan Advance Writing. Sesuai dengan jenjangnya, maka tingkat materi yang diajarkan juga berbeda. Namun, menurut penelitian mata kuliah witing disemua jenjang menjadi mata kuliah yang dianggap sangat sulit sebab untuk memiliki kemampuan menulis yang baik, maka mahasiswa harus mampu menggembangkan ide, mengorganisasikan ide tersebut dalam kalimat yang benar, memberikan tanda baca yang sesuai, dan isi tulisannya harus mudah dipahami oleh pembaca (Fikri Asih Wigati).

Terdapat lima komponen dalam menulis dan menghasilkan paragraf yang baik, yaitu; a) isi tulisan (content). Penulis harus memikirkan isi tulisan yang akan dibuat, hal ini berkaitan dengan pemilihan dan penggembangan ide kedalam tulisan, b) Organisasi (organization). Penulis harus mampu mengorganisasikan kalimat yang ada dalam tulisan dengan baik, dan juga mengorganisasikan alur ide (chronological order) sehingga pembaca mudah memahami alur kejadian/momen yang ada dalam tulisan, c) kosakata (vocabulary), pemilihan kosakata yang tepat akan menghindarkan ambigu pada pembaca, dan juga membuat tulisan mudah diinterpretasi isi, makna, dan tujuannya, d) Mekanik (mechanic) berkaitan dengan pemilihan atau penggunaan tanda baca, penulisan paragraf atau alinea baru, e) Struktur kalimat (grammar) adalah komponen yang paling penting dalam tulisan, sebab benar dan tidaknya penggunaan grammar akan mempengaruhi isi, organisasi, kosakata, dan mekanik yang terdapat dalam tulisan (Uswatun Hasanah).

Pada kenyataannya di kelas, banyak mahasiswa yang memiliki penguassan skill writing yang comprehensif tapi masih belum mampu membuat tulisan yang sesuai dengan komponen dalam writing. Menurut Santrock (2008) hal ini dipengaruhi oleh tingkat kepercayaan diri (self-efficacy) yang dimiliki oleh mahasiswa dalam mengembangkan ide yang mereka miliki, rasa ragu dan takut salah dalam membuat kalimat dan paragraph, serta kebingungan yang kadang muncul pada saat menentukan tata bahasa (grammatical), dan kossakata (vocabulary) yang sesuai. 
Self-efficacy dapat memberikan pengaruh yang kuat terhadap hasil belajar siswa, karena self-efficacy mempengaruhi pilihan tugas individu, tenaga, ketekunan, dan prestasi siswa (Schunk dan Meece 2006). Menurut Hairida self-efficacy diperlukan oleh pelajar untuk mencapai berbagai tujuan dalam pembelajaran, sebab pelajar dengan selfefficacy yang tinggi akan merasa yakin atau mampu menyelesaikan tugas yang diberikan dengan sukses.

Berdasarkan uraian tersebut maka selfefficacy pada mahasiswa perlu mendapatkan perhatian agar potensi dan motivasi siswa dalam belajar dapat dioptimalkan.

Peningkatan kemampuan menulis dan self-efficacy mahasiswa dapat tercapai salah satunya dengan penggunaan metode yang mendukung proses tersebut. Adapun metode yang dianggap sesuai adalah metode penilaian diri sendiri atau self-assessment. Assesment menjadi salah satu komponen penting dalam proses belajar mengajar dikelas karena merupakan acuan bagi mahasiswa dan dosen untuk mengukur perkembangan pemahaman terhadap materi atau konsep yang telah diajarkan atau dipelajari. Khusus untuk dosen, pemilihan dan penggunaan assesment yang tepat akan sangat membantu dalam menentukan sistem yang akan digunakan dalam pengajaran (Anizar Arsyad 2015).

Salah satu metode assessment yang dapat digunakan untuk meningkatkan hasil belajar dan rasa percaya diri mahasiswa dalam menulis adalah metode self-assessment. Motede ini membuat mahasiswa menilai sendiri hasil tulisan yang mereka telah buat, mencari tau kesalahan, memperbaiki, dan menghasilkan tulisan yang jauh lebih baik.

Dengan metode penilaian ini mahasiswa dapat mengevaluasi dan mengukur kelemahan dan kelebihan yang mereka miliki terkait dengan mata kuliah writing.

Berdasarkan uraian diatas, maka sangat urgen dilakukan uji coba dengan menggunakan metode self-assessment untuk mengetahui apakah ada peningkatan terhadap kemampuan menulis dan self-efficacy mahasiswa pada mata kuliah Intermediate Writing secara valid dan reliable. Sehingga, hasilnya dapat dimanfaatkan oleh dosen atau pengajar lainnya untuk penggembangan dan kualitas pembelajaran yang lebih baik.

\section{METODE}

Metode yang digunakan pada penelitian ini adalah pre-eksperimen dengan desain one group pre and posttest. Penelitian ini dilaksanakan di Program Studi Pendidikan Bahasa Inggris semester II angkatan 2020 STKIP Taman Siswa Bima, dengan sampel yang berjumlah 22 orang mahasiswa. Sampel terdiri dari satu kelas dengan menggunakan teknik purposive sampling. Sampel dipilih karena mata kuliah Intermediate Writing ada di semester II.

Prosedur penelitian terbagi menjadi 3 tahap yaitu :

Tahap 1 yang meliputi:

a. Observasi awal dan wawancara terkait kemampuan menulis, dan self-efficacy mahasiswa.

b. Penyusunan instrument pembelajaran dan penelitian

c. Penyusunan materi ajar

d. Validasi instrument pre dan post test

e. Uji coba instrument

f. Menganalisis hasil uji coba instrument Tahap II:
a. Melakukan pre-test
b. Pemberian treatment
c. Observasi self-efficacy mahasiswa
d. Melakukan post-test

Tahap III:

a. Mengolah data hasil pre-post test

b. Membandingkan hasilnya

c. Membuat kesimpulan penelitian Bagan penelitian:

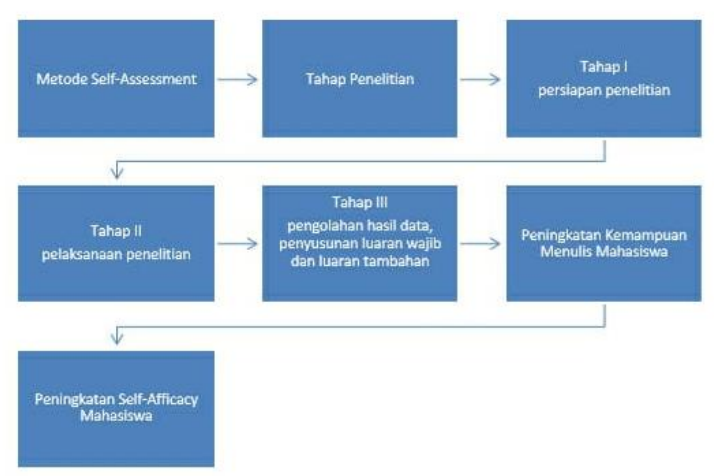




\section{HASIL DAN PEMBAHASAN}

Penelitian ini dilaksanakan di Program Studi Pendidikan Bahasa Inggris STKIP Taman Siswa Bima. Sampel pada penelitian ini adalah mahasiswa semester II angkatan 2020 yang berjumlah 22 orang mahasiswa yang mengikuti mata kuliah Intermediate Writing. tujuan penelitian ini adalah untuk meningkatkan kemampuan menulis dan self-efficacy mahasiswa dengan menggunkan metode selfassessment. Data diperoleh dari hasil pre-test, self-assessment oleh mahasiswa, penilaian kemampuan menulis, dan post-test.

Tabel 1. Data Hasil pre-test Mahasiswa

\begin{tabular}{|l|l|}
\hline Deskripsi & Pre-Test \\
\hline Nilai Minimun & 43 \\
\hline Nilai Maksimum & 65 \\
\hline Kategori nilai minimum & Very Poor \\
\hline Kategori nilai maksimum & $\begin{array}{l}\text { Good } \\
\text { average }\end{array}$ \\
\hline Rata-rata & 53,86 \\
\hline
\end{tabular}

Berdasarkan data hasil pre-test diketahui bahwa total nilai mahasiswa berdasarkan writing komponen (komponen penilaian dalam menulis), maka nilai minimum yang didapatkan oleh mahasiswa adalah 43 dengan kategori very poor (sangat buruk), dan nilai maksimum yang diperoleh adalah 65 dengan kategori good to average (baik). Data ini menunjukkan bahwa kemampuan menulis mahasiswa masih belum baik, banyak faktor yang menyebabkan hal ini, diantaranya adalah mahasiswa cenderung sulit dalam memulai tulisan, stigma bahwa menulis pada mata kuliah writing itu adalah kegiatan yang membosankan, serta tingkat percaya diri dalam mengembangkan ide-ide yang mereka miliki (Fika Megawati). Hal ini juga sejalan dengan yang dikemukakan oleh Fikri bahwa ada tiga hal yang membuat skill writing menjadi sulit untuk dikuasai yaitu permasalahn linguistik, kognitif, dan konten.

Tabel 2. Data Hasil Self-Assessment oleh Mahasiswa

\begin{tabular}{|c|c|c|}
\hline Jenis Teks & $\begin{array}{c}\text { Nilai } \\
\text { Minimum }\end{array}$ & $\begin{array}{c}\text { Nilai } \\
\text { Maksimal }\end{array}$ \\
\hline $\begin{array}{c}\text { Deskriptive } \\
\text { Teks }\end{array}$ & 40 & 78 \\
\hline Opinion & 50 & 85 \\
\hline
\end{tabular}

\begin{tabular}{|c|c|c|}
\hline Teks & & \\
\hline $\begin{array}{c}\text { Instruction } \\
\text { Teks }\end{array}$ & 58 & 85 \\
\hline $\begin{array}{c}\text { Recount } \\
\text { Teks }\end{array}$ & 60 & 85 \\
\hline $\begin{array}{c}\text { Narrative } \\
\text { Teks }\end{array}$ & 65 & 90 \\
\hline
\end{tabular}

Tabel diatas adalah data hasil penilaian kemampuan menulis mahasiswa dengan menggunkan metode self-assessment. Metode penilaian ini di lakukan oleh mahasiswa untuk mengukur kemampuan menulis mereka secara obyektif. Mahasiswa membuat tulisan dalam bentuk deskriptive teks sebanyak 3 kali dengan perolehan nilai minimum adalah 40 dan nilai maksimum adalah 78, opinion teks sebanyak 2 kali dengan nilai minimum 50 dan nilai maksimum 85, instruction teks sebanyak 2 kali dengan nilai minimum 58 dan nilai maksimum 85 , recount teks sebanyak 2 kali dengan nilai minimum 60 dan nilai maksimum 85, narrative teks sebanyak 2 kali dengan nilai minimum 65 dan nilai maksimum 90. Jadi mahasiswa menulis dan melakukan self-assessment sebanyak 11 kali selama penelitian berlangsung. Penggunaan metode self-assessment membuat mahasiswa dapat mengevaluasi kelebihan maupun kekurangan tulisan yang telah mereka buat, untuk selanjutnya kekurangan tersebut menjadi tujuan perbaikan (improvement gold) (Anizar Arsyad 2015). Adapun keuntungan penggunaan metode self-assessment menurut Nyai Ika Purnamah adalah: a) dapat menumbuhkan rasa percaya diri siswa/mahasiswa, b) siswa/mahasiswa dapat mengetahui kelebihan dan kelemahan dirinya, c) dapat mendorong, membiasakan, dan melatih siswa/mahasiswa untuk jujur, karena mereka dituntut untuk jujur dan obyektif dalam melakukan penilaian.

Tabel 3. Data hasil kemampuan menulis mahasiswa

\begin{tabular}{|c|c|c|}
\hline Jenis Teks & $\begin{array}{c}\text { Nilai } \\
\text { Minimum }\end{array}$ & $\begin{array}{c}\text { Nilai } \\
\text { Maksimal }\end{array}$ \\
\hline $\begin{array}{c}\text { Deskriptive } \\
\text { Teks }\end{array}$ & 45 & 78 \\
\hline $\begin{array}{c}\text { Opinion } \\
\text { Teks }\end{array}$ & 53 & 80 \\
\hline Instruction & 58 & 87 \\
\hline
\end{tabular}




\begin{tabular}{|c|c|c|}
\hline Teks & & \\
\hline $\begin{array}{c}\text { Recount } \\
\text { Teks }\end{array}$ & 63 & 90 \\
\hline $\begin{array}{c}\text { Narrative } \\
\text { Teks }\end{array}$ & 65 & 90 \\
\hline
\end{tabular}

Tabel di atas adalah data kemampuan menulis mahasiswa pada mata kuliah Intermediate writing. Data ini diberikan oleh dosen (Tim peneliti) berdasarkan writing component pada saat treatment dengan menggunakan metode self-assessment. Dari data pada tabel diketahui bahwa penilaian oleh mahasiswa dengan metode self-assessment sangat obyektif, hal ini dapat dibandingkan dengan nilai yang diberikan oleh tim peneliti.

Tabel 4. Data Hasil Post-Test

\begin{tabular}{|l|l|}
\hline Deskripsi & Pre-Test \\
\hline Nilai Minimun & 75 \\
\hline Nilai Maksimum & 90 \\
\hline Kategori nilai minimum & $\begin{array}{l}\text { Good to } \\
\text { average }\end{array}$ \\
\hline Kategori nilai maksimum & $\begin{array}{l}\text { Excellent to } \\
\text { very good }\end{array}$ \\
\hline Rata-rata & 81,63 \\
\hline
\end{tabular}

Pada tabel diatas disajikan hasil post-test mahasiswa pada mata kuliah Intermediate Writing dengan menggunakan metode selfassessment. Berdasarkan data pada tabel dapat disimpulkan bahwa terdapat peningkatan pada kemampuan menulis mahasiswa setelah diberikan treatment dengan menggunakan metode self-assessment. Metode penilaian selfassessment adalah metode penilaian diri sendiri yang dilakukan oleh mahasiswa secara obyektif terhadap hasil atau kemampuan menulis mereka. Dengan meningkatnya kemampuan menulis mahasiswa maka dapat disimpulkan bahwa tingkat self-efficacy mahasiswa juga ikut meningkat.

Rizal Rusdyanto menyatakan bahwa self-efficacy dapat diperoleh, diubah, ditingkatkan atau diturunkan melalui empat faktor yaitu; a) experience performance (pengalaman performansi), yaitu prestasi yang pernah dicapai pada masa yang lalu, b) vicarious experience (pengalaman vikarius), pengalaman yang meningkat ketika mengamati keberhasilan orang lain, c)social persuation (persuasi sosial) yaitu self-efficacy yang diperoleh atau diperkuat melaui persuasi sosial, emotional erousal (keadaan emosi), emosi yang kuat, takut, cemas, stres yang dapat mengurangi self-efficacy. Faktor -faktor tersebut diatas terpenuhi pada saat pemberian treatmen dengan menggunakan metode self-assessment sebab mahasiswa menilai, mengobservasi, dan berkompetisi dengan diri sendiri untuk menghasilkan tulisan yang baik.

Berdasarkan uraian diatas dapat disimpulkan bahwa penggunaan metode selfassessment efektif untuk meningkatkan kemampuan menulis dan meberikan kontribusi positif terhadap peningkatan self-efficacy mahasiswa pada mata kuliah Intermediate Writing

\section{KESIMPULAN}

Terjadi peningkatan kemampuan menulis dan self-efficacy mahasiswa pada mata kuliah Intermediate writing dengan pengaplikasian metode self-assessment yang cukup memuaskan. Peningkatan ini membuat mahasiswa mampu membuat tulisan yang baik, tidak ragu-ragu dan merasa takut dalam mengeksplor ide yang mereka miliki, dan menumbuhkan motivasi untuk lebih meningkatkan kemampuan yang mereka miliki.

\section{SARAN}

Penggunaan metode self-assessment pada penelitian ini menggunakan rubric dengan indikator yang cukup banyak, sehingga mahasiswa kesulitan dalam menentukan evaluasi tulisan yang telah dibuat harus dimasukkan dalam indikator yang mana, maka sangat disarankan untuk melakukan penggembangan rubric dan indikator selfassessment untuk lebih memudahkan dalam pengaplikasiannya.

\section{UCAPAN TERIMA KASIH}

Ucapan terima kasih Tim Peneliti tujukan kepada:

1. Kementrian Riset dan Teknologi/Badan Riset Inovasi Nasional

2. LLDIKTI Wilayah 8

3. STKIP Taman Siswa Bima 


\section{DAFTAR PUSTAKA}

Anizar Arsyad, Nadrun, Budi. 2015. Using selfassessment technique to improve students' writing skill of the eleventh grade. E-journal of English Language teaching Society (ELTS) Vol. 3 No. 2.

Anizar Arsyad, Nadrun, Budi. 2015. Using SelfAssessment Technique To Improve Students' Writing Skill Of The Elevent Grade. e-Journal of English Language Teaching Society (ELTS). Vol. 3. No. 2

Fika Megawati. 2016. Kesulitan Mahasiswa Dalam Mencapai Pembelajaran Bahasa Inggris Secara Efektif. Jurnal Pedagogia. Vol. 5. No. 2

Fikri Asih Wigati. 2014. Kesulitan Pada AspekAspek Writing Mahasiswa Dengan English Proficiency Levels yang Berbeda. Jurnal Ilmiah Solusi vol. 3

Hairida. (2017). Penggembangan Instrumen Untuk Mengukur Self-Efficacy Siswa Dalam Pembelajaran Kimia. EDUSAINS, 9 (1)

Hasanah, U. (2015). The Use Of SelfAssessment in Improving Students' Ability in Writing English Skill. Jurnal Ethical Lingua Vol.2, No. 1

Nyai Ika Purnamah, Nuryana, Euis Puspitasari. 2017. Penerapan Self-Assessment Untuk Menumbuhkan Kesadaran Siswa Tentang Makna Belajar Pada Mata Pelajaran IPS di MTs Sabilul Chalim Kecamatan Leuwimuding Kabupaten Majalengka. Jurnal Edueksos. Vol. VI No. 1

Rizal Rusdyanto. 2015. Hubungan Antara Tingkat Self-Efficacy Dengan Tingkat Kinerja Guru Di Sekolah Dasar Irada Gresik. Jurnal Psikosains. Vol. 10 no. 1

Santrock JW. (2008). Psikologi Pendidikan, Terjemahan Tri Wibowo B.S. Jakarta: Kencana.

Schunk DH, Meece JL. (2006). Self-Efficacy beliefs of Adolescences. Handbook (p71-96)

Wigati, F. (2014). Kesulitan Pada Aspek-Aspek Writing Mahasiswa Dengan English Proficiency Levels Yang Berbeda. Jurnal Ilmiah Sosial, vol 1 No.3, 46-61. 